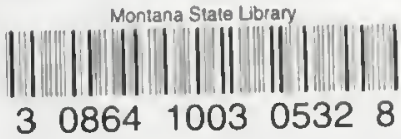

\title{
BIOLOGICAL INTEGRITY OF STREAMS IN THE NINEMILE CREEK TMDL PLANNING AREA BASED ON THE STRUCTURE AND COMPOSITION OF THE BENTHIC ALGAE COMMUNITY
}

\author{
Prepared for: \\ State of Montana \\ Department of Environmental Quality \\ P.O. Box 200901 \\ Helena, Montana 59620-0901 \\ Project Officer: Andrew Welch \\ DEQ Contract No. 200012-10
}

Prepared by:

Loren L. Bahls, Ph.D.

Hannaea

1032 Twelfth Avenue

Helena, Montana 59601

June 7, 2004

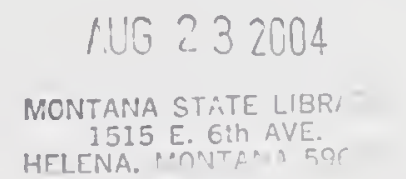


-

-

- 


\section{Summary}

In July of 2003, periphyton samples were collected from 8 sites on 5 streams in the Ninemile Creek TMDL planning area in west central Montana for the purpose of assessing whether these streams are water-quality limited and in need of TMDLs. The samples were collected following MDEQ standard operating procedures, processed and analyzed following standard methods for periphyton, and evaluated following modified USEPA rapid bioassessment protocols for wadcable streams.

A large percentage of motile diatoms suggest moderate impairment from sedimentation and partial support of aquatic life uses at the lower site on Josephine Creek. The siltation index suggests minor impairment from sedimentation but full support of uses at all of the remaining sites except Big Blue Creek. However, the siltation index for Big Blue Creek approached the threshold for minor impairment and this stream supported a large percentage of Planothidium species, which are adapted to living on sand grains.

Low or borderline values for the pollution index suggest minor impairment from organic loading at all sites except Big Blue Creek, where the pollution index was normal for a mountain stream. Most diatoms in lower McCormick Creek and upper Josephine Creek require only moderate levels of dissolved oxygen, compared to the continuously high levels required by diatoms in most mountain streams. Most diatoms in Josephine Creek (both sites) prefer alphamesosaprobous conditions, which is a higher level of saprobity than typical for most mountain streams. These three sites-lower McCormick Creek and the two sites on Josephine Creekappear to have higher levels of organic loading than the other sites.

Most diatoms at all sites in McCormick Creek and Josephine Creek were eutraphentic, a category that indicates elevated concentrations of inorganic nutrients. The majority of diatoms in upper Stony Creek were oligotraphentic and the majority of diatoms in lower Stony Creek were mesotraphentic. Most diatoms in Big Blue Creek and Cedar Creek tolerate a wide range of nutrient concentrations ranging from oligotrophic to eutrophic.

Among tributaries of Ninemile Creek, nitrogen-fixing blue-green algae were most abundant in McCormick Creek and Josephine Creek. These were also the only streams to support nitrogen-fixing diatoms. Nitrogen is most likely the limiting nutrient in these streams.

Five of the sites supported deformed diatom cells. In large numbers, abnormal cells may indicate metals toxicity. However, the percentage of abnormal cells was within acceptable limits at all sites. The largest percentage of abnormal cells (0.63\%) was recorded in Big Blue Creek. 


\section{Introduction}

This report evaluates the biological integrity ${ }^{1}$, support of aquatic life uses, and probable causes of stress or impairment to aquatic communities at 8 sites on 5 streams in the Ninemile Creek TMDL Planning Area of west central Montana. The purpose of this report is to provide information that will help the State of Montana determine whether these streams are waterquality limited and in need of TMDLs.

The federal Clean Water Act directs states to develop water pollution control plans (Total Maxinum Daily Loads or TMDLs) that set limits on pollution loading to water-quality limited waters. Water-quality limited waters are lakes and stream segments that do not meet waterquality standards, that is, that do not fully support their beneficial uses. The Clean Water Act and USEPA regulations require each state to (1) identify waters that are water-quality limited, (2) prioritize and target waters for TMDLs, and (3) develop TMDL plans to attain and maintain water-quality standards for all water-quality limited waters.

Evaluation of aquatic life use support in this report is based on the species composition and structure of periphyton (a.k.a. benthic algae, phytobenthos) communities at 8 sites on 5 streams that were sampled July $23-29,2003$. Periphyton is a diverse assortment of simple photosynthetic organisms called algae that live attached to or in close proximity of the stream bottom. Some algae form long filaments or large gelatinous colonies that are conspicuous to the unaided eye. However, most algae, including the ubiquitous diatoms, can be seen and identified only with the aid of a microscope. The periphyton community is a basic biological component of all aquatic ecosystems. Periphyton accounts for much of the primary production and biological diversity in Montana streams (Bahls et al. 1992). Plafkin et al. (1989) and Barbour et al. (1999) list several advantages of using periphyton in biological assessments.

\footnotetext{
'Biological integrity is defined as "the ability of an aquatic ecosystem to support and maintain a balanced, integrated, adaptive community of organisms having a species composition, diversity, and functional organization comparable to that of natural habitats within a region" (Karr and Dudley 1981).
} 


\section{Project Area and Sampling Sites}

The project area is located within the Northern Rockies Ecoregion (USEPA 2000). The streams in this study are all tributaries of Ninemile Creek. Ninemile Creek is a large north side tributary of the Clark Fork River, which it joins about 25 miles west of Missoula. The surface geology of the watershed is complex, consisting mostly of Precambrian Belt Series Rocks in the uplands and Tertiary basin fill in the Ninemile Valley (Renfro and Feray 1972). Climax vegetation consists of alpine tundra at the highest elevations, mixed conifer forest at intermediate elevations, and mixed grassland/sagebrush steppe in the Ninemile Valley. The main land uses are recreation, logging, and ranching.

Periphyton samples were collected at 8 sites on 5 tributaries of Ninemile Creek (Table 1). All sites are in USGS HUC 17010204 (Middle Clark Fork) and are classified B-1 in the Montana Surface Water Quality Standards.

\section{Methods}

Periphyton samples were collected following standard operating procedures of the MDEQ Planning, Prevention, and Assistance Division. Using appropriate tools, microalgae were scraped, bnished, or sucked from natural substrates in proportion to the importance of those substrates at each study site. Macroalgae were picked by hand in proportion to their abundance at the site. All collections of microalgae and macroalgae were pooled into a common container and preserved with Lugol's (IKI) solution.

The samples were examined to estimate the relative abundance of cells and rank by biovolume of diatoms and genera of soft (non-diatom) algae according to the method described in Bahls (1993). Soft algae were identified using Snith (1950), Prescott $(1962,1978)$, John et al. (2002), and Wehr and Sheath (2003). These books also served as references on the ecology of the soft algae, along with Palmer $(1969,1977)$. 
After the identification of soft algae, the raw periphyton samples were cleaned of organic matter using sulfuric acid, potassium dichromate, and hydrogen peroxide. Then permanent diatom slides were prepared using Naphrax ${ }^{\mathrm{TM}}$, a high refractive index mounting medium, following Standard Methods for the Examination of Water and Wastewater (APHA 1998). At least 400 diatom cells ( 800 valves) were counted at random and identified to species. The following were the main taxonomic references for the diatoms: Krammer and Lange-Bertalot 1986, 1988. 199 la, 199lb; Lange-Bertalot 1993, 2001; Krammer 1997a, 1997b, 2002; Reichardt 1997, 1999. Diatom naming conventions followed those adopted by the Integrated Taxonomic Information System (http://wnvv.itis.usda.gov). For taxa not yet included in ITIS, naming conventions followed those adopted by the Academy of Natural Sciences for USGS NAWQA samples (Morales and Potapova 2000). Van Dam et al. (1994) was the main ecological reference for the diatoms.

The diatom proportional counts were used to generate an array of diatom association metrics. A metric is a characteristic of the biota that changes in some predictable way with increased human influence (Barbour et al. 1999). Diatoms are particularly useful in generating metrics because there is a wealth of information available in the literature regarding the pollution tolerances and water quality preferences of common diatom species (e.g., Lowe 1974, Beaver 1981, Lange-Bertalot 1996, Van Dam et al. 1994).

Values for selected metrics were compared to biocriteria (numeric thresholds) developed for streams in the Rocky Mountain ecoregions of Montana (Table 2). These criteria are based on metric values measured in least-impaired reference streams (Bahls et al. 1992) and metric values measured in streams that are known to be impaired by various sources and causes of pollution (Bahls 1993). The criteria in Table 2 are valid only for samples collected during the summer field season (June 21-September 21). These criteria distinguish among four levels of stress or impairment and three levels of aquatic life use support: (1) no impairment or only minor impairment (full support); (2) moderate impairment (partial support); and (3) severe impairment (non-support). These impairment levels correspond to excellent, good, fair, and poor biological integrity, respectively. In cold, high-gradient mountain streams, natural stressors will often mimic the effects of man-caused impairment on some metric values. 


\section{Quality Assurance}

Several steps were taken to assure that the study results are accurate and reproducible. Upon receipt of the samples, station and sample attribute data were recorded in the Montana Diatom Database and the samples were assigned a unique number, e.g., 3046-01. The first part of this number (3046) designates the sampling site (Stony Creek near mouth) and the second part (01) designates the number of periphyton samples that that have been collected at this site for which data have been entered into the Montana Diatom Database.

Sample observations and analyses of soft (non-diatom) algae were recorded in a lab notebook along with information on the sample label. A portion of the raw sample was used to make duplicate diatom slides. The slides used for the diatom proportional counts will be deposited in the Montana Diatom Collection at the University of Montana Herbarium (MONTU) in Missoula. Duplicate slides will be retained by Hannaea in Helena. Diatom proportional counts have been entered into the Montana Diatom Database.

\section{Results and Discussion}

Results are presented in Tables 3, 4, 5, and 6 which are located near the end of this report following the references section. Appendix A contains a diatom report for each sample. Each diatom report includes an alphabetical list of diatom species in that sample and their percent abundances, and values for 66 different diatom metrics and ecological attributes.

\section{Sample Notes (Table 3)}

Notes on the contents and condition of each sample are recorded in Table 3. Most samples contained varying amounts of sediment, fine particulate organic matter, and plant material other than algae. 


\section{Non-Diatom Algae (Table 4)}

Twenty-two genera representing five divisions of non-diatom algae were found in samples that were collected from tributaries of Ninemile Creek (Table 4). Divisions represented by the most genera were the Chlorophyta or green algae ( 13 genera) and the Cyanophyta or cyanobacteria (6 genera). The Divisions Chrysophyta (yellow-green algae), Rhodophyta (red algae), and Phaeophaeta (brown algae) were represented by one genus each.

Cyanobacteria, mainly Nostoc and Oscillatoria, were found in all samples. Green algae were found in all but 1 sample (Big Blue Creek). The yellow-green alga Tribonema was common in 2 samples (lower McCormick and lower Josephine). The red alga Audouinella was found only in lower Josephine Creek. Heribaudiella fluviatilis, a rare freshwater brown alga [most other species of brown algae are marine], was found only in upper McCormick Creek. The number of genera of non-diatom algae ranged from 1 in Big Blue Creek to 13 in lower Josephine Creek.

Nitrogen-fixing Algae. Cyanobacteria that possess a certain type of specialized cell (heterocyst) are capable of fixing molecular or atmospheric nitrogen under aerobic conditions. These algae have a competitive advantage in waters where nitrogen is in short supply relative to phosphorus and other nutrients. Among tributaries of Ninemile Creek, genera of blue-green algae with heterocysts include Anabaena, Calothrix, Nostoc, and Tolypothrix. Collectively, these algae were most abundant in McCormick Creek and Josephine Creek (Table 4). Nitrogen is most likely the limiting nutrient in these streams.

Mat-forming Filamentous Algae. Large standing crops of filamentous algae can interfere with swimming, boating, fishing, and other water uses. Algal genera in tributaries of Ninemile Creek that are known to produce nuisance growths in North American waters are Oedogonium, Oscillatoria, Spirogyra, Ulothrix, and Zygnema (Wehr and Sheath 2003). One or more of these genera were dominant or abundant only in lower Stony Creek, where the green 
filamentous alga Oedogonium was abundant. Among sites represented by this sample set, lower Stony Creek is most likely to support nuisance growths of mat-forming filamentous algae.

Pollution-tolerant Algae. Palmer (1969) listed 60 algal genera that are most tolerant of organic pollution. Genera of non-diatom algae in this sample set that are among the top 22 on Palmer's list are Oscillatoria (\#2), Ankistrodesmus (\#10), Closterium (\#16), Spirogyra (\#21), and Anabaena (\#22). One or more of these genera were abundant or dominant only in lower McCormick Creek, where the blue-green alga Anabaena was abundant. On this basis, lower McCormick Creek most likely receives the heaviest load of organic matter among streams in the sample set. Genera among the 22 most pollution-tolerant algae were common or frequent in lower Stony Creek and lower Josephine Creek.

Other Indicator Algae. When abundant, certain genera of algae can provide useful clues about environmental conditions. The chrysophyte Tribonema, which is sensitive to organic pollution and prefers cool waters, was common in lower McCormick Creek and lower Josephine Creek. The filamentous green alga Mougeotia has often been reported to increase in abundance in lakes that are subject to atmospheric deposition and undergoing acidification. Among study sites in the Ninemile Creek TMDL planning area, cells of Mougeotia were frequent in lower Josephine Creek and occasional in McCormick Creek (both sites). The presence of the rare and pollution sensitive brown alga Heribaudiella indicates that upper McCormick Creek retains vestiges of the native algal flora and remains relatively unaffected by human disturbance.

\section{Diatoms (Table 5)}

Diatoms were frequent, abundant, or dominant and ranked first in biovolume in all of the samples (Table 4). All of the 16 major diatom species in tributaries of Ninemile Creek are either sensitive to organic pollution or only somewhat tolerant of organic pollution. None of the major diatom species is most tolerant of organic pollution (Table 5). 
In general, diatom species richness, diversity, and equitability were excellent. Most sites supported more than 40 species and diversity values in excess of 4.00 . None of the sites had a diversity or species richness value that indicates unusual stress. Only in lower McCormick Creek and Josephine Creek (both sites) did the dominant species contribute more than $25 \%$ of the cells to the diatom assemblage (Table 5). The cause of stress at these sites was probably a combination of sedimentation and elevated concentrations of inorganic nutrients.

High diatom diversity in these samples suggests the absence of extreme natural stressors, such as steep gradients, fast currents, low light, low nutrients, and constant cold temperatures. The abundance of non-motile, free-living taxa (Diatoma spp., Fragilaria spp., and Synedra spp.), attached species (Achnanthidium spp., Cocconeis placentula. Planothidium spp.), and motile, free-living taxa (Navicula spp. and Nitzschia spp.) suggests a wide variety of substrates, gradients, and current velocities. The disturbance index at most sites was relatively low, which suggests moderate gradients and slower current velocities than most mountain streams (Table 5).

Besides the absence of natural stressors and the presence of complex microhabitats, high diatom diversity in these streams also suggests moderate enrichment by organic and inorganic nutrients and little competition for available nutrients. Pollution index values, which indicate the amount of organic loading, are uniformly low for mountain streams. Many are at or below the threshold for minor impairment. Similarly, siltation index values tend to be higher in Ninemile Creek tributaries than in most mountain streams.

Five of the sites supported teratological (deformed or physically abnormal) diatom cells. In large numbers, abnormal cells may indicate metals toxicity. However, the percentage of abnormal cells was within acceptable limits at all sites. The largest percentage of abnormal cells $(0.63 \%)$ was recorded in Big Blue Creek (Table 5).

The similarity index ("percent community similarity") measures the cumulative percentage of cells of each taxon that are shared by two stream sites. The similarity index can be used to gauge the degree of environmental change that occurs between sites on the same stream. Similarity index values for Ninemile tributaries suggest that ecological changes between adjacent 
sites on the same stream varied from minor (40-60\% between the upper and lower McCormick Creek sites) to moderate (20-40\% between the two sites on Stony Creek and Josephine Creek).

The diatom order Rhopalodiales includes genera (Epithemia and Rhopalodia) that are known to harbor nitrogen-fixing endosymbionts within their cells. These symbiotic nitrogenfixers are single-celled cyanobacteria (blue-green algae). Nitrogen is likely the limiting nutrient in waters that support large numbers of diatoms in the order Rhopalodiales. Among tributaries to Ninemile Creek, diatoms in the order Rhopalodiales were present only in samples collected from McCormick Creek (both sites) and the lower site on Josephine Creek.

The following paragraphs highlight the key findings for each stream and each site based upon the major diatom species and core diatom metrics in Table 5.

Stony Creek. Both sites on Stony Creek had good biological integrity and provided full support of aquatic life uses. Borderline values for the pollution index and siltation index suggest minor impairment from organic loading and sedimentation at both sites. There was slightly more sedimentation and organic loading at the downstream site than at the upstream site (Table 5). A few teratological diatom cells were counted at the downstream site but none at the upstream site.

The major diatom species at the upstream site suggest slow current velocities and cold water (Diatoma mesodon and Meridion circulare), low pH (Eunotia muscicola), and sandy substrates (Planothidium spp.). The large percentage of Navicula perpusilla-an aerophilic species-suggests that the sample was collected from substrates that are intermittently wetted. Major species at the downstream site suggest faster current velocities (larger \% Achnanthidium minutissimum), somewhat warmer water temperatures, sandy substrates, and higher levels of inorganic nutrients (Fragilaria and Synedra spp.). The two sites shared 37\% of their diatom assemblages, which indicates that a minor to moderate change in environmental conditions occurred between them. 
McCormick Creek. Both sites on McCormick Creek suffer from minor scdimentation and organic loading. In addition, the upper site supported a few teratological diatom cells and the lower site supported large percentages of Fragilaria vaucheriae, Nitzschia archibaldii, and Synedra acus, all eutraphentic species that indicate elevated concentrations of inorganic nutrients. Nevertheless, both sites had good biological integrity and provided full support of aquatic life uses. The two sites on McCormick Creek shared $43 \%$ of their diatom assemblages, which indicates only minor environmental change from one site to the next.

Big Blue Creek. Aside from a few teratological cells, diatom metrics suggest excellent biological integrity, no impairment, and full support of aquatic life uses in Big Blue Creek. Although the siltation index was just below the threshold for minor impairment, this site did support a large percentage (22\%) of Planothidium species, which are adapted to living attached to sand grains. This site had the largest pollution index among streams in the sample set, which suggests that it receives less organic loading than the other sites.

Josephine Creek. Diatom metrics indicate minor impairment from sedimentation and organic loading at the upper site, which also supported a few teratological diatom cells. This site supported a large percentage (38\%) of Planothidium species, which are adapted to living on sand grains. Moreover, the upper site on Josephine Creek had the lowest diatom species richness and diversity values of all the sites in the sample set. This low diversity and species richness may be due, in part, to substrate instability. A large percentage of Diatoma mesodon-a cold-water stenotherm-indicates consistently cold water temperatures at this site.

\section{A large percentage of motile diatoms (46\%) suggest moderate impairment from} sedimentation at the downstream site on Josephine Creek. This site also had the lowest pollution index (2.27), which indicates minor to moderate impairment from organic loading. The dominant species at the lower site was Fragilaria vaucheriae, an eutraphentic species that indicates elevated concentrations of inorganic nutrients. The two sites on Josephine Creek shared $29 \%$ of their diatom assemblages, which suggests that there was a moderate change in environmental conditions between them. 
Cedar Creek. Diatom metrics suggest minor impairment from sedimentation and organic loading in Cedar Creek. However, the sedimentation index-38\% motile cells-was close to the threshold for moderate impairment, which is $40 \%$. One teratological diatom cell was counted at this site. The dominant species (Navicula cryptotenella. Nitzschia dissipata, Synedra rumpens, Synedra ulna), which are all cosmopolitan "increasers", indicate a habitat disturbed by human activities and somewhat elevated concentrations of inorganic nutrients.

\section{Modal Categories (Table 6)}

Several ecological attributes assigned by Stevenson and Van Dam et al. (1994) were selected from the diatom reports in the appendix. Modal categories of these attributes were extracted to characterize water quality tendencies in tributaries of Ninemile Creek (Table 6).

The majority of diatoms at most sites were non-motile, nitrogen autotrophs that prefer alkaline fresh waters, moderate BOD levels, high oxygen levels, and elevated concentrations of inorganic nutrients. However, the modal categories at some sites represent significant departures in water quality when compared to most other sites in the sample set. These departures, which may reflect increases or decreases in water quality, are discussed below. Several sites were dominated by diatom species that have not been classified with respect to one or more water quality categories.

Diatom species that prefer circumneutral (as opposed to alkaline) $\mathrm{pH}$ values were most abundant in Stony Creek and Big Blue Creek. These streams are likely to have lower $\mathrm{pH}$ values than the other streams.

The modal category for oxygen demand was "continuously high" in Big Blue Creek and upper Stony Creek. This is the nominal category for mountain streams. Most diatoms were in the "moderate" category in lower McCormick Creek and upper Josephine Creek. Most cells at the remaining sites were represented by species that have not been classified with regard to oxygen demand. 
Beta-mesosaprobous was the usual level of saprobity at most sites. This represents a dissolved oxygen saturation level of $70-85 \%$ and a biochemical oxygen demand $\left(\mathrm{BOD}_{5}\right)$ of $2-4$ $\mathrm{mg} / \mathrm{L}$. However, saprobity levels were higher at both sites on Josephine Creek, where most of the diatoms were alpha-mesosaprobous. The alpha-mesosaprobous level corresponds to $25-70 \%$ saturation of dissolved oxygen and 4-13 mg/L BOD 5 . Most diatoms at upper Stony Creek were in the oligosaprobous category. This is the lowest level of organic loading and represents $>85 \%$ oxygen saturation and a $\mathrm{BOD}_{5}$ concentration of $<2 \mathrm{mg} / \mathrm{L}$.

Most sites in the Ninemile Creek TMDL planning area were dominated by eutraphentic diatom species. One site-lower Stony Creek - was dominated by mesotraphentic species. Mesotraphentic is the next trophic level below (less enriched than) eutraphentic. Upper Stony Creek was dominated by oligotraphentic diatoms, which prefer even smaller concentrations of inorganic nutrients than mesotraphentic species. Two sites-Big Blue Creek and Cedar Creekwere dominated by species that tolerate a wide range of trophic levels ranging from oligotrophic to eutrophic.

\section{References}

APHA. 1998. Standard Methods for the Examination of Water and Wastewater. 20 $0^{\text {th }}$ Edition. American Public Health Association, Washington, D.C.

Bahls, L.L. 1979. Benthic diatom diversity as a measure of water quality. Proceedings of the Montana Academy of Sciences 38:1-6.

Bahls, L.L. 1993. Periphyton Bioassessment Methods for Montana Streams (revised). Montana Department of Health and Environmental Sciences, Helena.

Bahls, L.L., Bob Bukantis, and Steve Tralles. 1992. Benchmark Biology of Montana Reference Streams. Montana Department of Health and Environmental Sciences, Helena.

Barbour, M.T., J. Gerritsen, B.D. Snyder, and J.B. Stribling. 1999. Rapid Bioassessment Protocols for Use In Streams and Wadeable Rivers: Periphyton, Benthic Macroinvertebrates and Fish. Second Edition. EPA/841-B-99-002. U.S. Environmental Protection Agency, Office of Water, Washington, D.C.

Beaver, Janet. 1981. Apparent Ecological Characteristics of Some Common Freshwater Diatons. Ontario Ministry of The Environment, Technical Support Section, Don Mills, Ontario.

Johansen, J.R. 1999. Diatoms of Aerial Habitats. Chapter 12 in Stoermer, E.F., and J.P. Smol (eds.), The Diatoms: Applications For the Environmental and Earth Sciences, Cambridge University Press, New York.

John, D.M., B.A. Whitton, and A.J. Brook (eds.). 2002. The Freshwater Algal Flora of the British Isles: An Identification Guide to Freshwater and Terrestrial Algae. Cambridge University Press, Cambridge, U.K. 
Karr. J.R., and D.R. Dudley. 1981. Ecological perspectives on water quality goals. Environmental Management 5:55-69.

Kawecka, B. 1990. The effect of flood-control regulation of a montane stream on the communities of sessile algae. Acta Hydrobiology 32:345-354.

Krammer, Kurt. 1997a. Die cymbelloiden Diatomeen: Eine Monographie der weltweit bekannten Taxa. Teil 1. Allgemeines and Encyonema Part. J. Cramer, Berlin.

Krammer, Kurt. 1997b. Die cymbelloiden Diatomeen: Eine Monographie der weltweit bekannten Taxa. Teil 2. Encyonema part., Encyonopsis and Cymbellopsis. J. Cramer, Berlin.

Krammer, Kurt. 2002. Cymbella. Volume 3 in Diatoms of Europe, Horst Lange-Bertalot, ed. A.R.G. Gantner Verlag K.G., Germany.

Krammer, K., and H. Lange-Bertalot. 1986. Bacillariophyceae, Part 2, Volume 1: Naviculaceae. In Ettl, H., J Gerloff, H. Heynig, and D. Mollenhauer (eds.), Freshwater Flora of Middle Europe. Gustav Fischer Publisher, New York.

Kranmer, K., and H. Lange-Bertalot. 198S. Bacillariophyceae, Part 2, Volume 2: Bacillariaceae, Epithemiaceae, Surirellaceae. In Ettl, H., J. Gerloff, H. Heynig, and D. Mollenhauer (eds.), Freshwater Flora of Middle Europe. Gustav Fischer Publisher, New York.

Krammer, K., and H. Lange-Bertalot. 1991a. Bacillariophyceae, Part 2, Volume 3: Centrales, Fragilariaceae, Eunotiaceae. In Ettl, H., J. Gerloff, H. Heynig, and D. Mollenhauer (eds.), Freshwater Flora of Middle Europe. Gustav Fischer Publisher, Stuttgart.

Krammer, K., and H. Lange-Bertalot. 1991b. Bacillariophyceae, Part 2, Volume 4: Achnanthaceae, Critical Supplement to Navicula (Lineolatae) and Gomphonema, Complete List of Literature for Volumes 1-4. In Ettl, H., G. Gartner, J. Gerloff, H. Heynig, and D. Mollenhauer (eds.), Freshwater Flora of Middle Europe. Gustav Fischer Publisher, Stuttgart.

Lange-Bertalot, Horst. 1979. Pollution tolerance of diatoms as a criterion for water quality estimation. Nova Hedwigia 64:285-304.

Lange-Bertalot, Horst. 1993. 85 new taxa and much more than 100 taxonomic clarifications supplementary to Susswasserflora von Mitteleuropa Vol. 2/1-4. J. Cramer, Berlin.

Lange-Bertalot, Horst. 1996. Rote Liste der limnischen Kieselalgen (Bacillariophyceae) Deutschlands. Schr.-R. f. Vegetationskde., H. 28, pp. 633-677. BfN, Bonn-Bad Godesberg.

Lange-Bertalot, Horst. 2001. Navicula sensu stricto: 10 Genera Separated from Navicula sensu lato; Frustulia. Volume 2 in Diatoms of Europe, Horst Lange-Bertalot, ed. A.R.G. Gantner Verlag K.G., Germany.

Lowe, R.L. 1974. Environmental Requirements and Pollution Tolerance of Freshwater Diatoms. EPA-670/4-74-005. U.S. Environmental Protection Agency, National Environmental Research Center, Office of Research and Development, Cincinnati, Ohio.

McFarland, B.H., B.H. Hill, and W.T. Willingham. 1997. Abnormal Fragilaria spp. (Bacillariophyceae) In streams impacted by mine drainage. Journal of Freshwater Ecology 12(1):141-149.

Nicholls, K.H., and D.E.Wujek. 2003. Chrysophycean Algae. Chapter 12 (pp. $471-509$ ) in Wehr, J.D., and R.G. Sheath (eds.), Freshwater Algae of North America: Ecology and Classification. Academic Press, New York.

Palmer, C.M. 1969. A composite rating of algae tolerating organic pollution. Journal of Phycology 5:78-82. 
Palmer, C.M. 1977. Algae and Water Pollution: An Illustrated Manual on the Identification, Significance, and Control of Algae in Water Supplies and in Polluted Water. EPA-600/9-77-036.

Plafkin, J.L., M.T. Barbour, K.D. Porter, S.K. Gross, and R.M. Hughes. 1989. Rapid Bioassessment Protocols for Use in Rivers and Streams: Benthic Macroinvertebrates and Fish. EPA 440-4-89-001.

Prescott, G.W. 1962. Algae of the Western Great Lakes Area. Wm. C. Brown Company, Dubuque, Iowa.

Prescott, G.W. 1978. How to Know the Freshwater Algae. Third Edition. Wm. C. Brown Company Publishers, Dubuque, Iowa.

Reichardt, Erwin. 1997. Taxonomische Revision des Artenkomplexes um Gomphonema pumilum (Bacillariophyta). Nova Hedwigia 65(1-4):99-129.

Reichardt, Erwin. 1999. Zur Revision der Gattung Gomphonema. A.R.G. Gantner Verlag, Distributed by Koeltz Scientific Books, Konigstein, Germany.

Renfro, H.B., and D.E. Feray. 1972. Geological Highway Map of the Northern Rocky Mountain Region. American Association of Petroleum Geologists, Tulsa, Oklahoma.

Smith, G.M. 1950. The Fresh-Water Algae of The United States. McGraw-Hill Book Company, New York.

Stevenson, R.J., and Y. Pan. 1999. Assessing Environmental Conditions in Rivers and Streams with Diatoms. Chapter 2 in Stoermer, E.F., and J.P. Smol (eds.), The Diatoms: Applications For the Environmental and Earth Sciences, Cambridge University Press, New York.

Stewart, W.D.P., P. Rowell, and A.N. Rai. 1980. Symbiotic Nitrogen-Fixing Cyanobacteria. Pp. 239-277 in Stewart, W.D.P., and J. Gallo (eds.), Nitrogen Fixation, Academic Press, New York.

USDA. 1976. Climax Vegetation of Montana (map). U.S. Department of Agriculture, Soil Conservation Service, Cartographic Unit, Portland.

USEPA. 2000. Level 111 Ecoregions of the Continental United States (map). National Health and Environmental Effects Research Laboratory, U.S. Environmental Protection Agency, Corvallis, Oregon.

Van Dam, Herman, Adrienne Mertens, and Jos Sinkeldam. 1994. A coded checklist and ecological Indicator values of freshwater diatons from The Netherlands. Netherlands Journal of Aquatic Ecology 28(1):117-133.

Weber, C.I. (ed.). 1973. Biological Field and Laboratory Methods for Measuring the Quality of Surface Waters and Effluents. EPA-670/4-73-001. U.S. Environmental Protection Agency, National Environmental Research Center, Office of Research and Development, Cincinnati, Ohio.

Wehr, J.D., and R.G. Sheath. 2003. Freshwater Algae of North America: Ecology and Classification. Academic Press, New York.

Whittaker, R.H. 1952. A study of summer foliage insect communities in the Great Smoky Mountains. Ecological Monographs 22:1-44.

Woods, A.J., Omernik, J.M., Nesser, J.A., Shelden, J., and S.H. Azevedo. 1999. Ecoregions of Montana (color poster with map), U.S. Geological Survey, Reston, Virginia. 


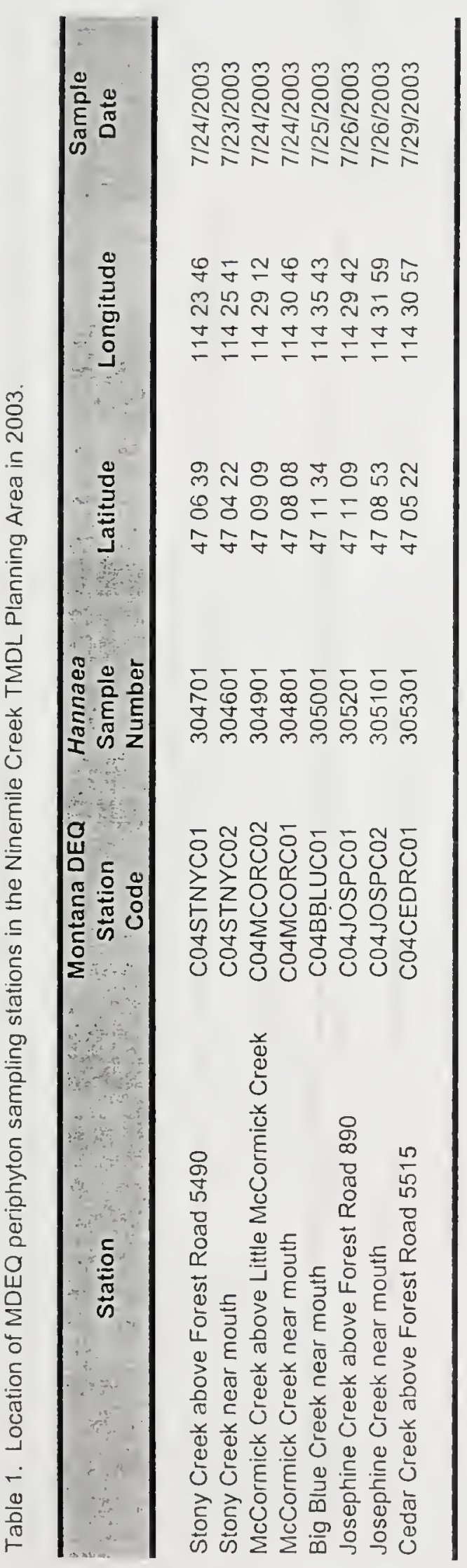




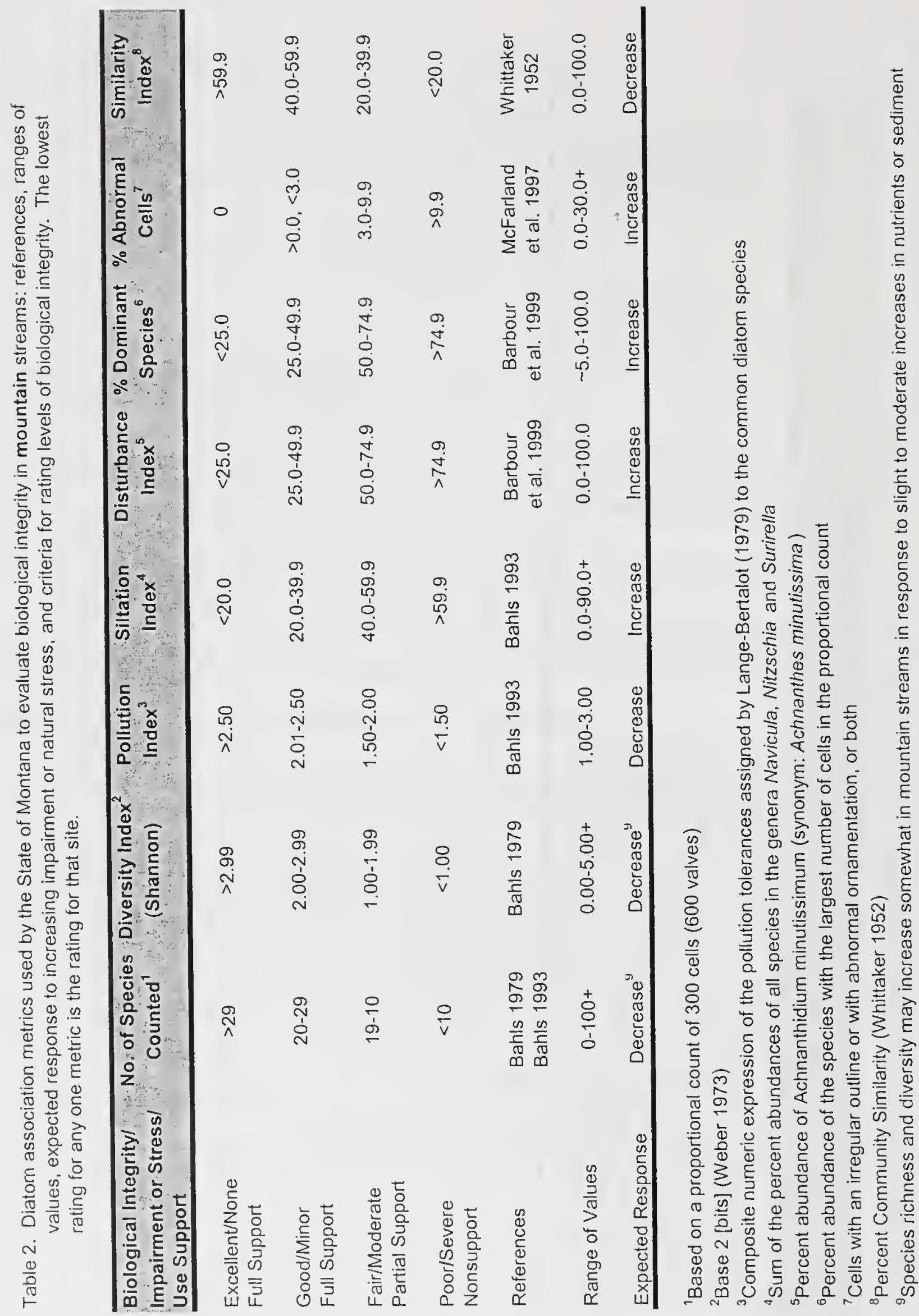




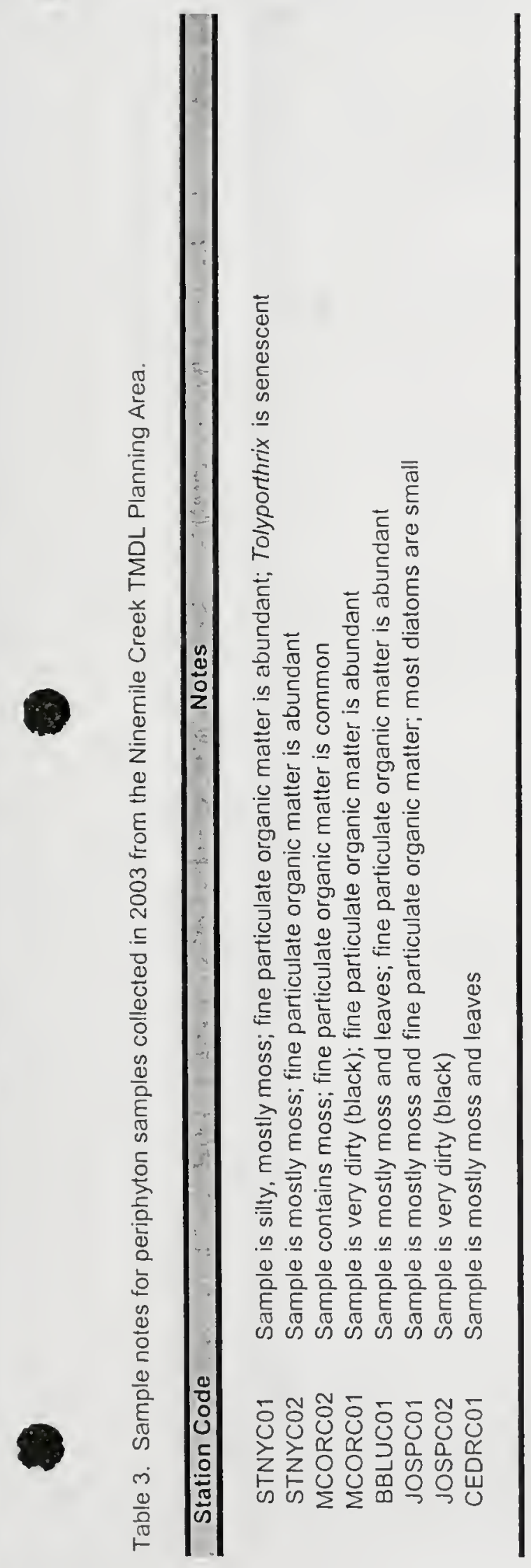




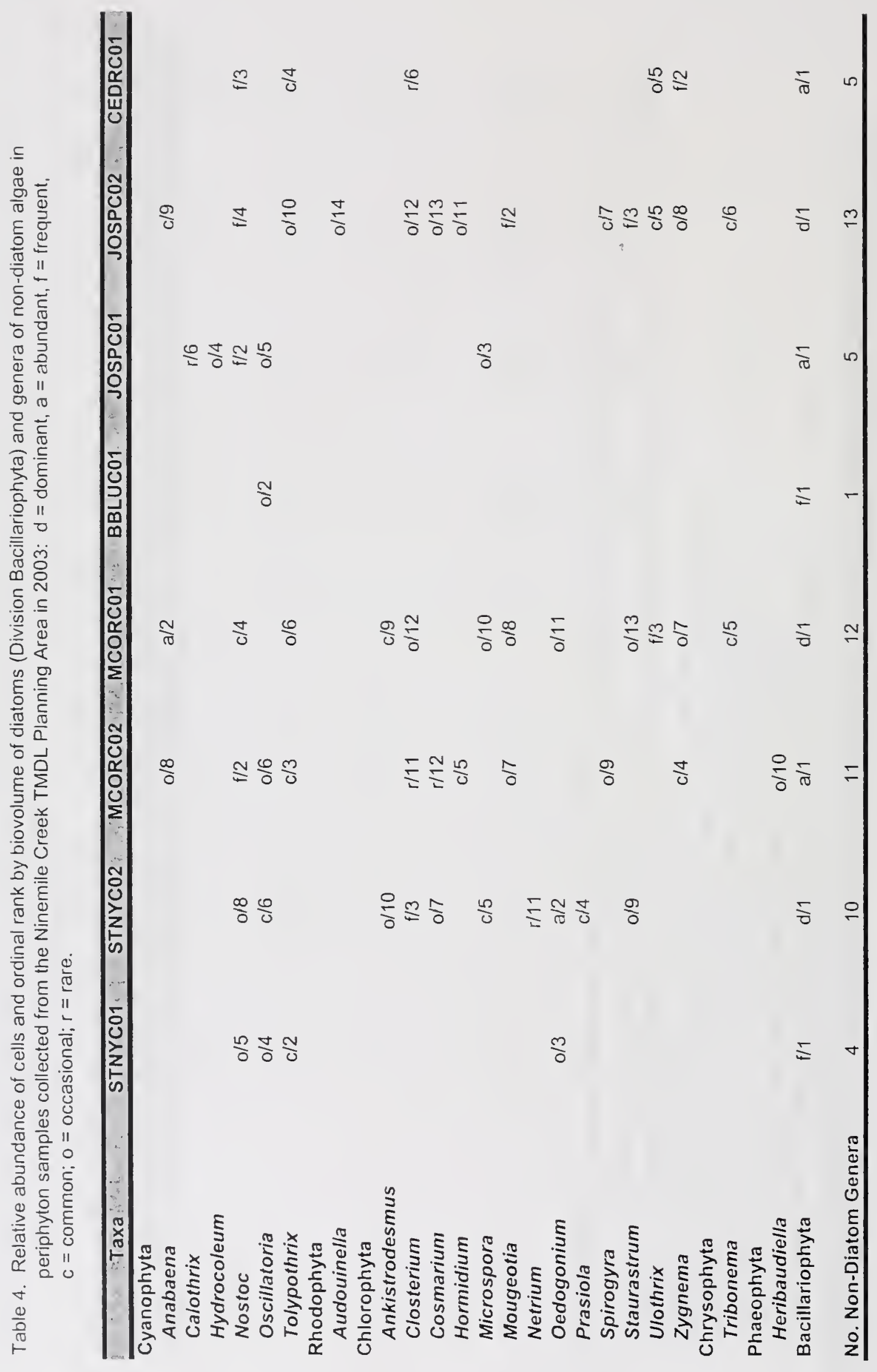




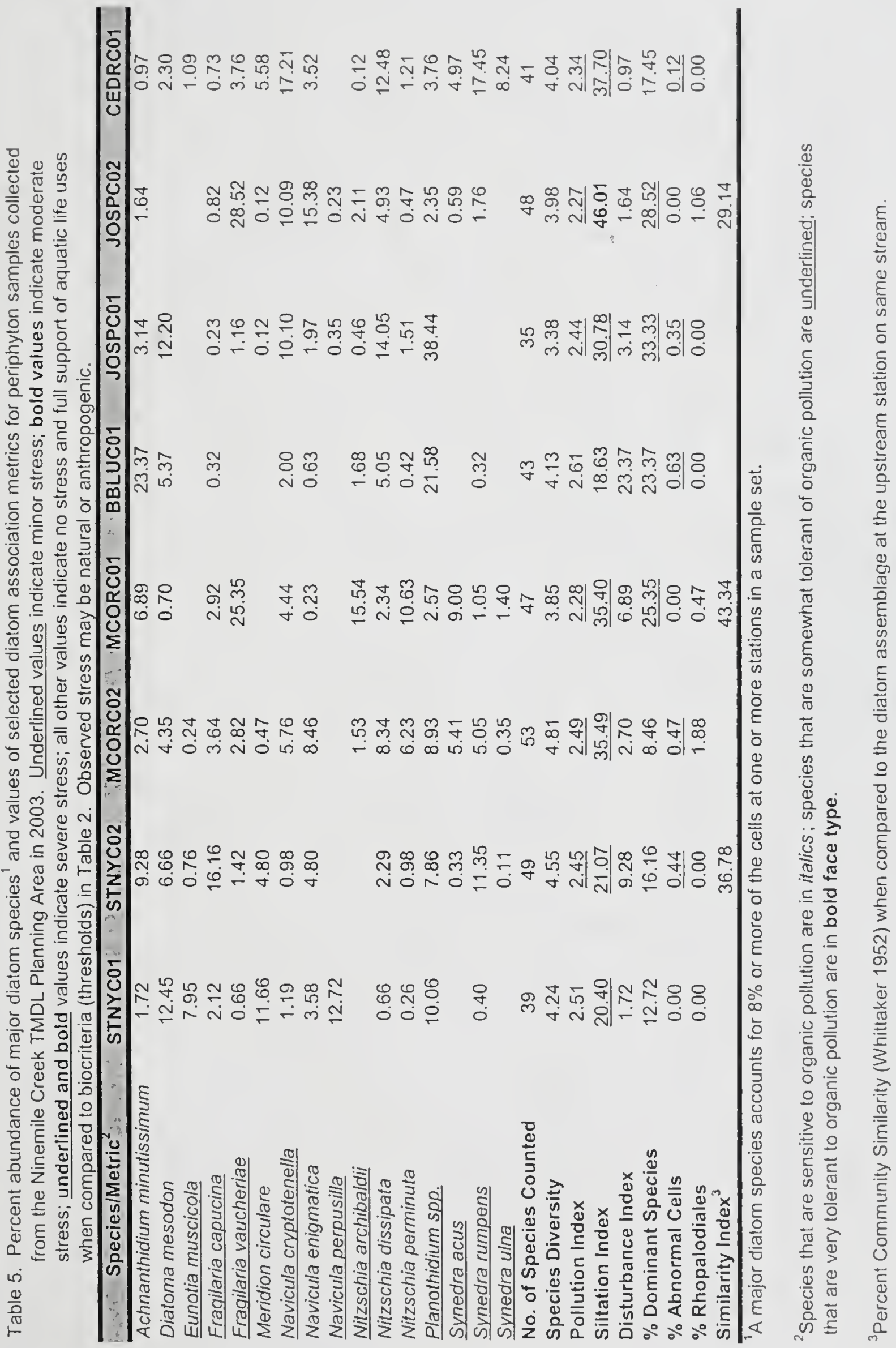




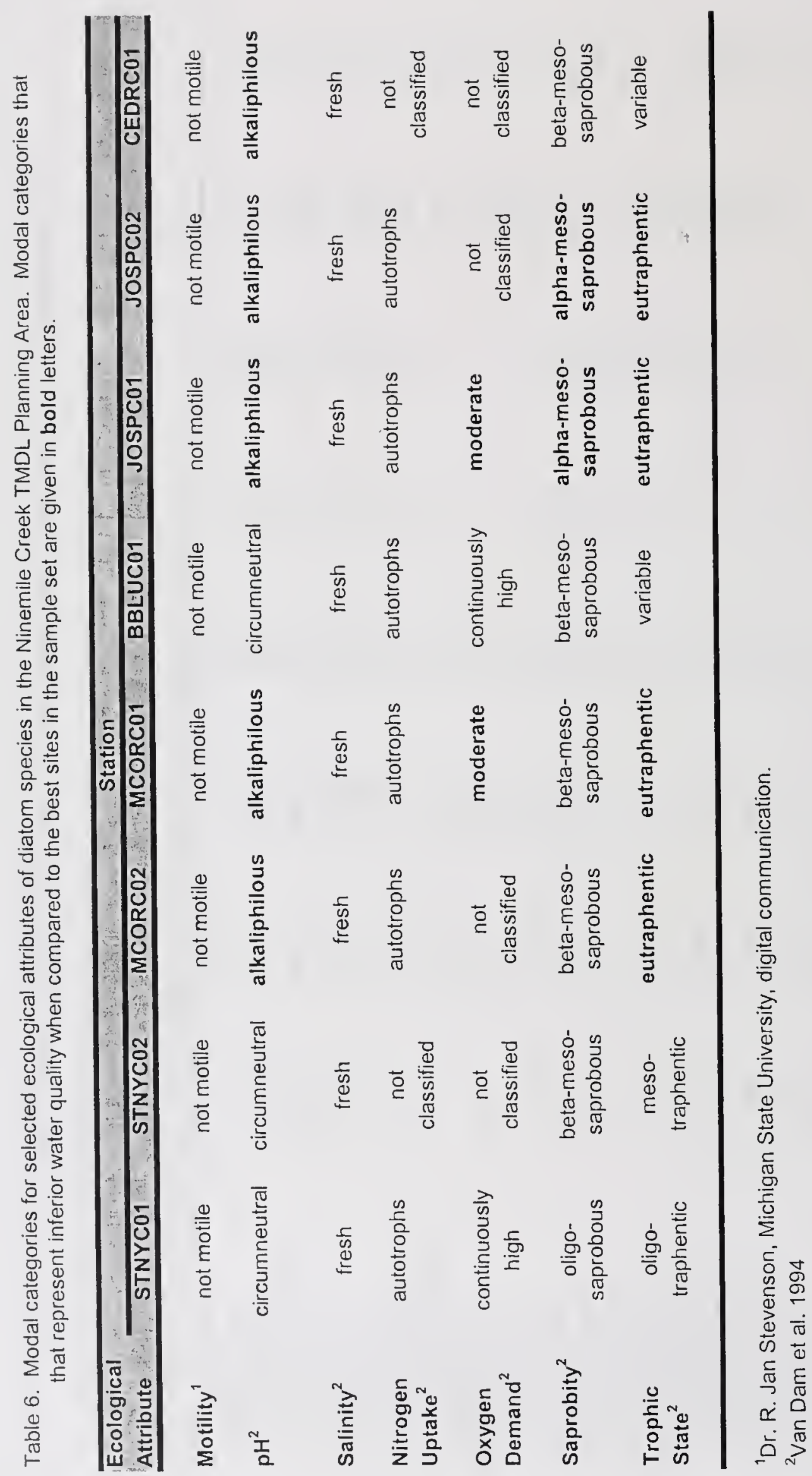

